\title{
THE SPATIAL AND TEMPORAL PATTERNS OF STICK-NEST RAT MIDDENS IN AUSTRALIA
}

\author{
Stuart Pearson ${ }^{1} \cdot$ Ewan Lawson $^{2} \cdot$ Lesley Head $^{3} \bullet$ Lynne McCarthy $^{3} \bullet$ John Dodson $^{4}$
}

\begin{abstract}
The spatial and temporal distribution of 145 radiocarbon dates on 66 Australian stick-nest rat middens (Muridae: Leporillus spp.) range from modern to 10,900 \pm 90 BP. As in American packrat middens, age frequency follows a logarithmic decay, both continentally and at major sites. This is probably a result of natural decay processes. Unlike American middens of similar age, relatively few range changes in plant distribution have been detected in Australia. The distribution of ${ }^{14} \mathrm{C}$ ages and the associated midden materials provide important paleoenvironmental information from the arid interior of Australia. The middens record subtle changes in vegetation and dramatic changes in the fauna unlike those interpreted from sites on the coastal rim or the southeastern periphery of the arid zone.
\end{abstract}

\section{INTRODUCTION}

Stick-nest rats are in eclipse; Leporillus apicalis is extinct, and Leporillus conditor is the subject of an intensive recovery program from its refuge on Franklin Island, South Australia (Pedler and Copley 1993). However, the stick-nest rat middens have survived on the mainland and are a feature of many caves and overhangs in arid Australia. To our knowledge, the first published analysis of fossil middens in Australia is that of Green et al. (1983). The materials in the middens, and the distributions of the middens themselves, provide useful biological information about the surrounding area. This information is readily dated using radiocarbon methods (Berry 1993; Pearson and Dodson 1993; McCarthy et al. 1996). Head et al. (1998) found that a weak relationship existed between midden appearance and age, although a stronger relationship existed between appearance and the resolution of the paleoecological record in the midden. The majority of middens in Australia are found in deeply weathered rocks that erode to form shallow caves, rock shelters and overhangs along a low cliff-line or breakaway (Copley 1988). Other animals, such as rock wallabies and brush-tailed possums, may also be responsible for ancient excretory deposits in rock shelters, although the distinctive stick-nests discussed in this paper can be attributed to stick-nest rats (Pearson 1997).

From the sizeable number of conventional and accelerator mass spectrometry (AMS) ${ }^{14} \mathrm{C}$ analyses, we review the temporal distribution of the Australian midden record. Similar reviews (Mead et al. 1978; Van Devender et al. 1985; Webb 1986; Webb and Betancourt 1990) on packrat middens in the United States have helped focus subsequent efforts in North America. The North American findings include: reconstruction of vegetation distributions over the last 40,000 yr (e.g. Betancourt et al. 1990; Van Devender et al. 1990), isotopic analysis (e.g. Long et al. 1990; Pendall et al. 1999), analysis of insect communities (e.g. Elias et al. 1995), vertebrate fauna reconstructions using preserved remains (e.g. Mead and Phillips 1981; Mead et al. 1994), protein analysis on desiccated urine (Rogers and Bendich 1985; Lowenstein et al. 1991), stomatal responses to prehistoric atmospheric change (Van de Water et al. 1994), and atmospheric radionuclide production rates (Plummer et al. 1997). Many of the analyses are possible without the cost of additional fieldwork or ${ }^{14} \mathrm{C}$ dating because the material is not destroyed in analysis and much of it is stored in archives. Here we review the patterns of stick-nest rat midden dates from Australia, highlight the spatial and temporal extent of the record, and discuss new applications to the material that has already been ${ }^{14} \mathrm{C}$ dated.

\footnotetext{
${ }^{1}$ School of Geography, University of New South Wales, Sydney, Australia. Present address: Department of Geography and Environmental Science, University of Newcastle, Callaghan 2308, Australia

2 Antares AMS Physics Division (Lucas Heights), ANSTO, PMB 1 Menai, 2234, Australia

${ }^{3}$ School of Geosciences, University of Wollongong, Wollongong, 2522, Australia

${ }^{4}$ Department of Geography University of Western Australia, Stirling Highways, Nedlands, 6907, Australia
} 


\section{METHODS}

We list all ${ }^{14} \mathrm{C}$ analyses known to us from published and unpublished work of researchers pursuing stick-nest rat midden analysis through March 1998. Sample collectors and submitters include Sandra Berry, John Dodson, Lesley Head, Lynne McCarthy, Stuart Pearson, Jay Quade, and Robert Webb. Table 1 records all known ${ }^{14} \mathrm{C}$ dates; analyses have not been subject to any exclusion criteria. For various reasons, not all the sample data we wished to review could be obtained from submitters or laboratories. A number of dates have been revised (in all cases by the laboratory). Details of samples sent to Beta Analytic Inc. were not available due to confidentiality and the destruction of their data warehouse by Hurricane Andrew in 1992.

The majority of the analyses have been done through the Australian Nuclear Science and Technology Organisation (ANSTO) using AMS. There was good analog evidence from the packrat work that this would allow rapid advances in midden analysis by identifying contamination, taphonomic processes and direct dates on special material (Van Devender et al. 1985). There is some debate about the selection of ${ }^{14} \mathrm{C}$ samples in packrat middens (see Mead and Phillips 1981). In North America most analyses have dated specific material from plants that are not found in the local area and, for the last decade, packrat scats have been dated to save other macrofossil material for analysis (Webb and Betancourt 1990).

The early conventional ${ }^{14} \mathrm{C}$ analyses from stick-nest rat middens were on bulk unwashed material and may have included mixtures of non-contemporaneous materials (Green et al. 1983; Berry 1993). Pearson (1989) used pads of finely chewed organic material (either grasses or Acacia phyllodes) for his conventional analyses. These layers appeared to have been accumulated quickly because they lacked a dusty coating or induration by desiccated urine or scats. Compared to larger woody debris, this finer material was also less likely to survive long on cave floors or be reworked through deposits. Samples were between $7 \mathrm{~g}$ and $20 \mathrm{~g}$ dry weight. Pretreatment by Beta Analytic Inc. included: examination for contamination such as rootlets, acid soaking to remove carbonates, rinsing to neutrality, drying, and combustion in an enclosed line before benzene synthesis and counting.

Pearson (1997) used AMS on the scats to date the rodent activity more directly than the analysis of other materials that may have been recycled from elsewhere. The usual protocol was for 1 scat (about $1 \mathrm{~g}$ ) to be separated for ${ }^{14} \mathrm{C}$, and 5 other scats, closely associated in the matrix of the dated sample, were prepared for pollen analyses. This provided the closest context for interpreting the pollen record. Pretreatment of the (AMS) ${ }^{14} \mathrm{C}$ samples was done at the ANSTO ANTARES Facility. Other material was pretreated at the NWG Macintosh Centre for Quaternary Dating at the University of Sydney, the NSF-Arizona AMS Laboratory at the University of Arizona, and at Beta Analytic Inc.

The facilities at Beta Analytic Inc. (liquid scintillation counters) and ANSTO report machine background contamination levels that would only affect samples older than about 40,000 yr. The correction due to contamination from combustion and graphitization was that associated with $2.5 \mu \mathrm{g}$ modern carbon equivalent. ${ }^{14} \mathrm{C}$ ages reported here are determined using the NIST Oxalic Acid I (HOx1) standard. Counting errors are quoted to $\pm 1 \sigma$. The estimation of the $\delta^{13} \mathrm{C}$ correction ratio for samples was left to the laboratory and measured $\delta^{13} \mathrm{C}$ corrections are not yet available for many samples. The estimated normalized $\delta^{13} \mathrm{C}$ correction ranged from $-12 \%$ to $-27 \%$ and reflected the expectation that the material dated was isotopically similar to wood. The measured corrections that are available $(n=22)$ are within this range $(-24.7 \pm 2.1 \% o)$. The ratio of $\mathrm{C}-3$ to $\mathrm{C}-4$ pathway plants in a sample may significantly affect the $\delta^{13} \mathrm{C}$ correction. However, these differences in corrections could, at worst, result in a $60-y r$ change in the age result within the ranges of the age determinations. 
We separated the dates on specific parts of stick-nest rat middens ("selected dates") from the population of ${ }^{14} \mathrm{C}$ analyses ("all dates") in order to show the different distribution of the ${ }^{14} \mathrm{C}$ samples and the middens. Webb and Betancourt (1990) analyzed the patterns of all ${ }^{14} \mathrm{C}$ analyses because selection of one date to represent a midden was intractable. However, with the analysis of stick-nest rat midden dates, we have been able to select the oldest and youngest dates available from a midden. This corrects the number of repeated dates on a few middens and provides information about initiation construction and abandonment of a specific midden. We will refer to these 3 groups of dates as "all dates", "selected maximal dates" and "selected minimal dates".

Organic material found in the midden is certain to predate, and possibly postdate, the construction of the midden. The history of ${ }^{14} \mathrm{C}$ in samples from middens must be carefully considered on an individual basis (Pearson 1999) and is not considered in this summary. Amberat is a black matrix of desiccated urine, including phytoliths (Bowdery 1998), pollen and other midden debris. Presumably it contains a range of organic material from many sources; contaminates may make samples appear older. Instances of younger contaminates entering the midden have been recognized (Pearson 1997; Pearson et al. 1999) and this demands careful consideration of each sample, and greater understanding of the taphonomy of the deposits (Pearson 1999). The only sampling bias we are aware of is that Stuart Pearson avoided middens with no induration because they are likely to be contaminated and tend to disintegrate in sampling (Pearson 1989) - this may have resulted in relatively modern middens being under-represented in his samples.

We subtracted $24 \mathrm{yr}$ from the dates older than $100 \mathrm{BP}$ as the Southern Hemispheric offset, assuming the offset is unimportant after AD 1850 (Stuiver et al. 1998). We used CALIB 4.0 (Stuiver and Reimer 1993, 1998) to calibrate each ${ }^{14} \mathrm{C}$ date with the 1998 atmospheric decadal dataset (Stuiver et al. 1998) and created the $1 \sigma$ probabilities of each date. This was done in 2 batches to resolve the data-entry limitations of Calib 4.0. The probabilities were summed to show the maximum amount of data from the ${ }^{14} \mathrm{C}$ analyses. We did not use a moving average in the calibration curve because the material sampled spanned an unknown period. The probabilities of each ${ }^{14} \mathrm{C}$ estimate were summed into 10-yr categories then exported into Excel® for graphing.

\section{RESULTS}

The spatial distribution of stick-nest rat middens is described in Copley (1988). The maximum likely midden extent follows the subfossil distribution of stick-nest rats in Australia (Strahan 1995). Middens recently found in Queensland (G Medlin and C Dollery, personal communication 1998) extend the range of fossil middens. The distribution shows the effects of an extensive search effort across central Australia and a concurrent intense effort in the Flinders Ranges and western New South Wales.

Table 1 lists all the ${ }^{14} \mathrm{C}$ analyses on material from stick-nest rat middens. Spreadsheet versions are available from the corresponding author-empty cells indicate unavailable information. The temporal distribution of all calibrated ${ }^{14} \mathrm{C}$ ages is shown on Figure 1; Figure 2 shows the selected samples that show the minimal and maximal ages on middens, and Figure 3 shows the spatial distribution of study sites and ${ }^{14} \mathrm{C}$ results. Figure 4 shows the spatial distribution of all ${ }^{14} \mathrm{C}$ ages during 4 periods in Australia. The oldest Flinders Ranges dates, 10,000-8000 BP, are based on 2 middens, SAJQ85 (dated 8 times) and SAJQ79 (dated once). Nine Flinders Ranges middens dated older than 5000 BP. Figure 5 shows the summed probability distributions from the maximal and minimal ${ }^{14} \mathrm{C}$ dates for 4 sites. These sites were graphed because a number of dates were available. At Umbeara Station and Gap Range all the middens found were dated. Figure 5 shows the relation between both initial construction dates (maximal ${ }^{14} \mathrm{C}$ dates) and abandonment (minimal) dates in a variety of locations. 
Table 1 Radiocarbon analyses on material in stick-nest rat middens

\begin{tabular}{|c|c|c|c|c|c|}
\hline $\begin{array}{c}{ }^{14} \mathrm{C} \text { age } \\
(\mathrm{yr} \mathrm{BP} \pm 1 \sigma)\end{array}$ & a & Lab code & Material used & $\delta^{13} C^{b}$ & $\mathrm{c}$ \\
\hline $10,900 \pm 90$ & A & OZA-318 & Scats & -25.0 & $\max$ \\
\hline $10,870 \pm 80$ & $\mathrm{C}$ & ANU-8109 & Plant \& scat & & \\
\hline $10,870 \pm 80$ & & BETA-67214 & Plant & -25.0 & \\
\hline $10,630 \pm 100$ & $\mathrm{C}$ & ANU-8138 & Plant & -24 & \\
\hline $10,550 \pm 460$ & A & OZA-317 & Plant & -24.0 & \\
\hline $9473 \pm 319$ & A & OZA-319 & Plant & -25.0 & \\
\hline $9420 \pm 80$ & $\mathrm{C}$ & ANU-8110 & Plant \& scat & -20.0 & \\
\hline $9060 \pm 70$ & $\mathrm{C}$ & ANU-8137 & Amberat & -27.0 & \\
\hline $8820 \pm 150$ & $\mathrm{C}$ & ANU-7754 & Plant & -24.0 & \\
\hline $7720 \pm 90$ & A & BETA-81092 & Scat & & $\max$ \\
\hline $7400 \pm 90$ & A & BETA-8108 & Scat & & \\
\hline $7310 \pm 90$ & A & BETA-81090 & Scat & & $\max$ \\
\hline $7260 \pm 100$ & $\mathrm{~A}$ & OZC-6152 & Scat & & only \\
\hline $7200 \pm 220$ & A & OZA-316 & Scat & -25.0 & $\max$ \\
\hline $6930 \pm 80$ & A & BETA-81091 & Scat & & $\min$ \\
\hline $6920 \pm 50$ & A & BETA-87302 & Leaf & & \\
\hline $6880 \pm 50$ & A & BETA-87301 & Leaf & & \\
\hline $6800 \pm 70$ & A & OZB-292 & Plant & & $\min$ \\
\hline $6710 \pm 80$ & A & OZB-291 & Plant & & \\
\hline $6650 \pm 80$ & A & OZB-297 & Plant & & \\
\hline $6610 \pm 90$ & A & OZB-296 & Scat & & \\
\hline $6580 \pm 60$ & A & BETA-87300 & Leaf & & \\
\hline $6520 \pm 50$ & A & BETA-87299 & Leaf & & \\
\hline $6520 \pm 50$ & A & BETA-91808 & Plant & & \\
\hline $6472 \pm 163$ & A & OZA-31? & Leaf & -27.0 & \\
\hline $6470 \pm 60$ & A & BETA-91809 & Scats & & $\max$ \\
\hline $6380 \pm 70$ & $\mathrm{C}$ & ANU-8136 & Plant & -12.0 & \\
\hline $6380 \pm 70$ & $\mathrm{C}$ & ANU-8138 & Amberat & & $\min$ \\
\hline $6360 \pm 100$ & $\mathrm{C}$ & BETA-89611 & Plant & & \\
\hline $6360 \pm 100$ & $\mathrm{C}$ & BETA-89613 & Plant & & \\
\hline $6290 \pm 190$ & A & OZB-295 & Plant & & \\
\hline $5790 \pm 80$ & A & OZC-047 & Scat & -26.5 & \\
\hline $5710 \pm 90$ & $\mathrm{C}$ & BETA-89609 & Plant & & \\
\hline $5690 \pm 70$ & A & OZB-294 & Scat & & \\
\hline $5540 \pm 110$ & A & OZA-315 & Plant & -27.0 & $\min$ \\
\hline $5340 \pm 70$ & $\mathrm{C}$ & ANU-8139 & Plant & -25.0 & only \\
\hline $5340 \pm 90$ & $\mathrm{C}$ & BETA-91810 & Plant & & \\
\hline $5240 \pm 90$ & $\mathrm{C}$ & BETA-91807 & Plant & & \\
\hline $5020 \pm 70$ & A & OZC-049 & Scat & -27.8 & only \\
\hline $4350 \pm 60$ & $\mathrm{~A}$ & OZC-046 & Scat & -24.2 & $\max$ \\
\hline $3790 \pm 90$ & A & OZB-300 & Scat & & \\
\hline $3690 \pm 180$ & A & OZB-298 & Plant & & $\max$ \\
\hline $3670 \pm 70$ & $\mathrm{~A}$ & OZC-6172 & Scat & & $\max$ \\
\hline $3640 \pm 70$ & A & OZB-293 & Scat & & \\
\hline
\end{tabular}


Table 1 Radiocarbon analyses on material in stick-nest rat middens (Continued)

\begin{tabular}{|c|c|c|c|c|c|}
\hline $\begin{array}{c}{ }^{14} \mathrm{C} \text { age } \\
(\mathrm{yr} \mathrm{BP} \pm 1 \sigma)\end{array}$ & $\mathrm{a}$ & Lab code & Material used & $\delta^{13} C^{b}$ & $\mathrm{c}$ \\
\hline $3570 \pm 120$ & A & OZB-299 & Plant & & $\min$ \\
\hline $3500 \pm 90$ & $\mathrm{C}$ & BETA-23022 & Plant & & $\max$ \\
\hline $3450 \pm 70$ & A & OZA-189 & Amberat & -23.8 & $\max$ \\
\hline $3430 \pm 70$ & A & BETA-89612 & Plant & & \\
\hline $3430 \pm 50$ & A & OZB-168 & Amberat & -25.0 & only \\
\hline $3350 \pm 80$ & A & OZA-1882 & Scat & -25.0 & \\
\hline $3330 \pm 190$ & A & OZA-190 & Plant & -24.4 & \\
\hline $3310 \pm 80$ & A & OZA-1881 & Scat & -25.0 & $\min$ \\
\hline $3040 \pm 70$ & $\mathrm{C}$ & BETA-89606 & Amberat & & $\max$ \\
\hline $2960 \pm 100$ & $\mathrm{C}$ & BETA-97075 & Amberat & & \\
\hline $2950 \pm 200$ & A & OZA-309 & & -25.0 & \\
\hline $2780 \pm 100$ & $\mathrm{C}$ & A-3990 & Plant & & $\max$ \\
\hline $2680 \pm 60$ & $\mathrm{C}$ & BETA-80610 & Amberat & & $\max$ \\
\hline $2430 \pm 70$ & A & OZA-308 & Plant & -23.6 & \\
\hline $2430 \pm 80$ & A & OZC-618 & Scat & & $\min$ \\
\hline $2400 \pm 290$ & A & OZA-980 & Scat & -25.0 & \\
\hline $2380 \pm 40$ & A & OZA-963 & Plant & -25.0 & $\max$ \\
\hline $2330 \pm 120$ & A & OZA-187 & Plant & -27.0 & $\max$ \\
\hline $2280 \pm 120$ & A & OZA-186 & Scat & -25.0 & \\
\hline $1950 \pm 70$ & C & BETA-67212 & Plant & -25.0 & $\max$ \\
\hline $1920 \pm 110$ & $\mathrm{C}$ & ANU-7753 & Plant & -24.0 & only \\
\hline $1840 \pm 100$ & $\mathrm{C}$ & ANU-2385 & Charcoal & & \\
\hline $1820 \pm 40$ & A & OZA-978 & Wood & -25.0 & $\max$ \\
\hline $1720 \pm 60$ & A & OZA-969 & Scat & -25.0 & only \\
\hline $1700 \pm 90$ & $\mathrm{C}$ & BETA-23023 & Plant & & $\min$ \\
\hline $1660 \pm 100$ & $\mathrm{C}$ & A-3989 & Plant & & $\min$ \\
\hline $1610 \pm 50$ & A & OZA-975 & Scat & -25.0 & $\max$ \\
\hline $1600 \pm 50$ & A & OZA-310 & & -25.0 & $\max$ \\
\hline $1540 \pm 110$ & A & OZA-181 & Plant & -27.0 & \\
\hline $1530 \pm 50$ & A & OZA-182 & Scat & -25.0 & \\
\hline $1480 \pm 140$ & $\mathrm{C}$ & BETA-30954 & Plant & -25.0 & only \\
\hline $1470 \pm 70$ & $\mathrm{C}$ & BETA-76575 & Plant & -25.0 & only \\
\hline $1430 \pm 50$ & A & OZA976 & Scat & -25.0 & $\max$ \\
\hline $1380 \pm 60$ & A & BETA-91811 & Scats & & $\min$ \\
\hline $1310 \pm 60$ & A & OZA964 & Bark & -25.0 & only \\
\hline $1300 \pm 80$ & $\mathrm{C}$ & ANU8140 & Plant & -27 & $\max$ \\
\hline $1300 \pm 40$ & A & OZA312 & Wood & & \\
\hline $1280 \pm 70$ & A & OZC620 & Scat & & \\
\hline $1150 \pm 100$ & $\mathrm{C}$ & BETA-30956 & Plant & -25.0 & $\max$ \\
\hline $1150 \pm 50$ & A & OZA-962 & Scat & -25.0 & \\
\hline $1140 \pm 40$ & A & OZA-967 & Scat & -25.0 & only \\
\hline $1130 \pm 60$ & A & OZA-183 & Scat & -21.3 & $\max$ \\
\hline $1120 \pm 50$ & A & OZA-974 & Scat & -25.0 & $\min$ \\
\hline $1000 \pm 70$ & & BETA-62204 & Plant & -25.0 & only \\
\hline
\end{tabular}


Table 1 Radiocarbon analyses on material in stick-nest rat middens (Continued)

\begin{tabular}{|c|c|c|c|c|c|}
\hline $\begin{array}{c}{ }^{14} \mathrm{C} \text { age } \\
(\mathrm{yr} \mathrm{BP} \pm 1 \sigma)\end{array}$ & $\mathrm{a}$ & Lab code & Material used & $\delta^{13} C^{b}$ & c \\
\hline $1000 \pm 70$ & A & OZA-313 & Wood & -24.6 & \\
\hline $961 \pm 145$ & A & OZA-311 & Plant & -24.6 & $\min$ \\
\hline $940 \pm 60$ & A & OZA-184 & Plant & -27.0 & $\min$ \\
\hline $900 \pm 90$ & $\mathrm{C}$ & BETA-30957 & Scat & -25.0 & $\max$ \\
\hline $900 \pm 45$ & A & OZA-167 & Scat & -25.0 & $\min$ \\
\hline $880 \pm 75$ & A & OZC-616 & Plant & & only \\
\hline $880 \pm 150$ & A & OZC-6211 & Scat & & \\
\hline $800 \pm 80$ & $\mathrm{C}$ & BETA-68230 & Plant & -25.0 & $\max$ \\
\hline $780 \pm 80$ & $\mathrm{C}$ & BETA-89607 & Wood & & only \\
\hline $770 \pm 70$ & A & OZC-041 & Scat & -27.2 & $\max$ \\
\hline $710 \pm 80$ & $\mathrm{C}$ & BETA-30955 & Plant & -25.0 & $\min$ \\
\hline $700 \pm 95$ & A & OZA-977 & Scat & -25.0 & $\min$ \\
\hline $630 \pm 100$ & & BETA-62205 & Plant & -25.0 & $\min$ \\
\hline $620 \pm 55$ & A & OZC-044 & Plant & -27.5 & $\max$ \\
\hline $610 \pm 40$ & A & OZA-973 & Scat & -25.0 & \\
\hline $590 \pm 55$ & $\mathrm{C}$ & BETA-76571 & Plant & -25.0 & $\max$ \\
\hline $590 \pm 45$ & A & OZC-040 & Scat & & $\min$ \\
\hline $590 \pm 50$ & A & OZC-623 & Plant & & \\
\hline $560 \pm 60$ & A & OZC-048 & Scat & -19.4 & $\min$ \\
\hline $530 \pm 80$ & $\mathrm{C}$ & BETA-86307 & Wood & & \\
\hline $530 \pm 70$ & A & OZA-185 & Scat & -25.8 & $\min$ \\
\hline $510 \pm 70$ & $\mathrm{C}$ & BETA-59079 & Plant & & \\
\hline $510 \pm 50$ & A & OZA-966 & Scat & -25.0 & only \\
\hline $510 \pm 70$ & A & OZA-979 & Scat & -25.0 & $\min$ \\
\hline $470 \pm 65$ & A & OZC-045 & Scat & -24.1 & $\min$ \\
\hline $470 \pm 130$ & A & OZC-619 & Scat & & only \\
\hline $460 \pm 90$ & $\mathrm{C}$ & BETA-59080 & Plant & & \\
\hline $450 \pm 60$ & A & OZC-043 & Plant & -26.3 & $\max$ \\
\hline $430 \pm 35$ & A & OZB-164 & Scat & -25.0 & only \\
\hline $420 \pm 50$ & A & OZC-042 & Plant & -27.4 & $\min$ \\
\hline $410 \pm 165$ & A & OZA-192 & Plant & -27.0 & $\max$ \\
\hline $410 \pm 40$ & A & OZA-314 & Scat & -25.0 & $\max$ \\
\hline $410 \pm 65$ & A & OZC-625 & Scat & & \\
\hline $385 \pm 140$ & A & OZC-614 & Plant & & \\
\hline $380 \pm 60$ & $\mathrm{C}$ & BETA-89608 & Amberat & & only \\
\hline $360 \pm 50$ & A & OZA965 & Plant & -25.0 & \\
\hline $360 \pm 75$ & A & OZB 165 & Scat & -25.0 & only \\
\hline $340 \pm 40$ & A & OZA968 & Scat & -25.0 & $\min$ \\
\hline $340 \pm 55$ & A & OZB 166 & Scat & -25.0 & only \\
\hline $310 \pm 70$ & $\mathrm{C}$ & BETA-59078 & Plant & & $\max$ \\
\hline $310 \pm 40$ & A & OZA-961 & Scat & -25.0 & only \\
\hline $300 \pm 90$ & $\mathrm{C}$ & BETA-30958 & Plant & -25.0 & $\min$ \\
\hline $300 \pm 50$ & A & OZA970 & Scat & -25.0 & only \\
\hline $280 \pm 40$ & A & BETA-86305 & Wood & & only \\
\hline
\end{tabular}


Table 1 Radiocarbon analyses on material in stick-nest rat middens (Continued)

\begin{tabular}{ccllcr}
\hline $\begin{array}{c}{ }^{14} \mathrm{C} \text { age } \\
(\mathrm{yr} \mathrm{BP} \pm 1 \sigma)\end{array}$ & a & Lab code & Material used & $\delta^{13} \mathrm{C}^{\mathrm{b}}$ & $\mathrm{c}$ \\
\hline $270 \pm 40$ & A & BETA-86306 & Scats & & $\mathrm{min}$ \\
$250 \pm 60$ & $\mathrm{C}$ & BETA-76573 & Plant & -25.0 & \\
$230 \pm 105$ & A & OZC-6221 & Scat & & \\
$220 \pm 70$ & C & BETA-59077 & Wood & & min \\
$200 \pm 55$ & A & OZA-972 & Scat & -25.0 & $\mathrm{~min}$ \\
$170 \pm 60$ & C & BETA-76577 & Plant & -25.0 & \\
$80 \pm 50$ & A & OZA-968 & Plant & -25.0 & \\
$80 \pm 50$ & C & BETA-76576 & Plant & -25.0 & $\min$ \\
$20 \pm 80$ & C & BETA-68231 & Plant & -25.0 & min \\
104.34 & A & OZC-624 & Seeds & & \\
pMC $\pm 0.7 \%$ & & & & & \\
101.1 & C & BETA-76574 & Plant & -25.0 & min \\
pMC $\pm 0.7 \%$ & & & & & \\
101.55 & A & OZA-191 & Skin & -21.8 & \\
pMC $\pm 0.4 \%$ & & & & & \\
See text & A & & Scat & -25.0 & \\
\hline
\end{tabular}

aAMS or conventional method

${ }^{\mathrm{b}}$ Corrections that are estimated rather than measured are shown in italics.

'Interpreted as minimal, only or maximal age (see text)

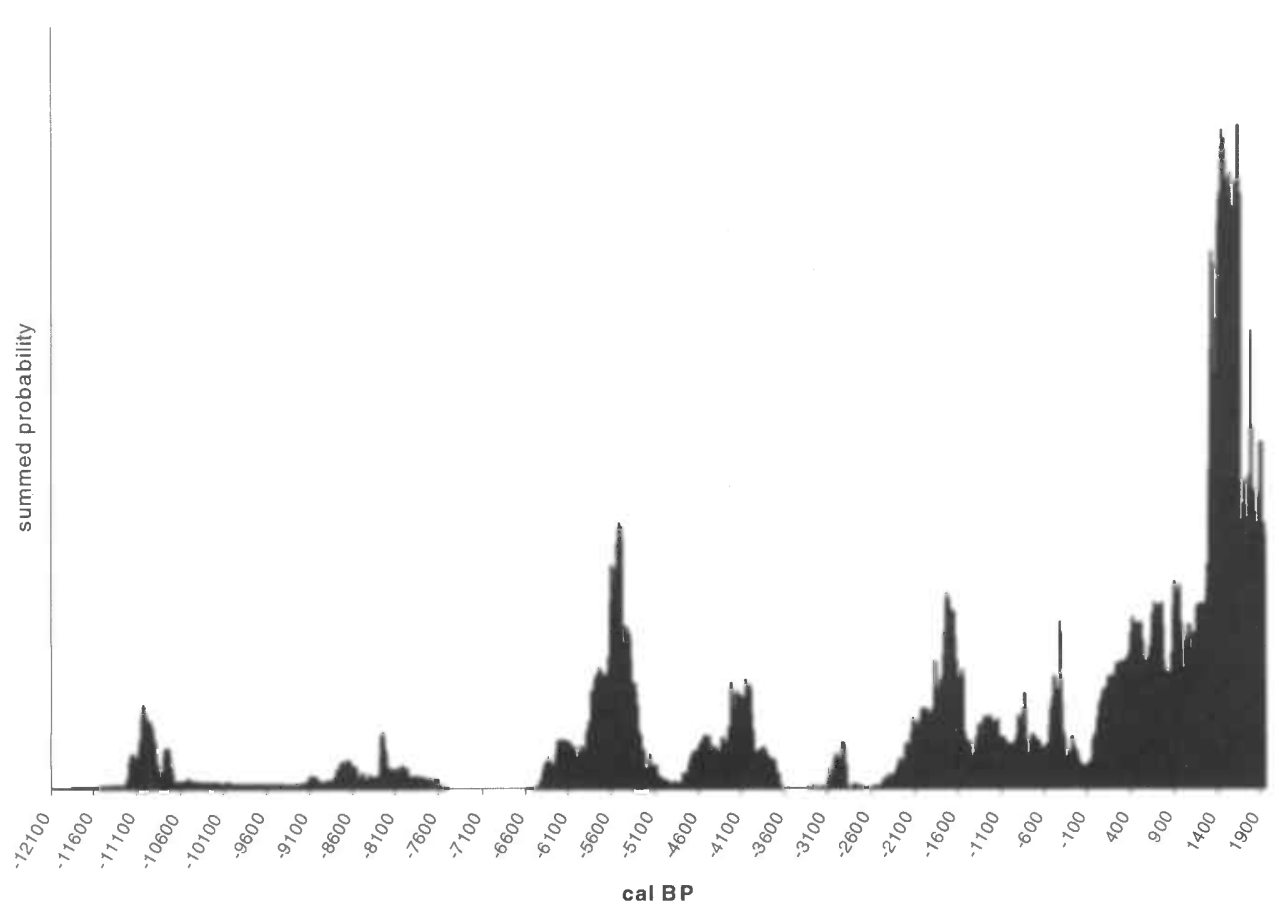

Figure 1 Distribution of calibrated dates on stick-nest rat middens 
Figure 2 Distribution of maximal dates and minimal dates on middens

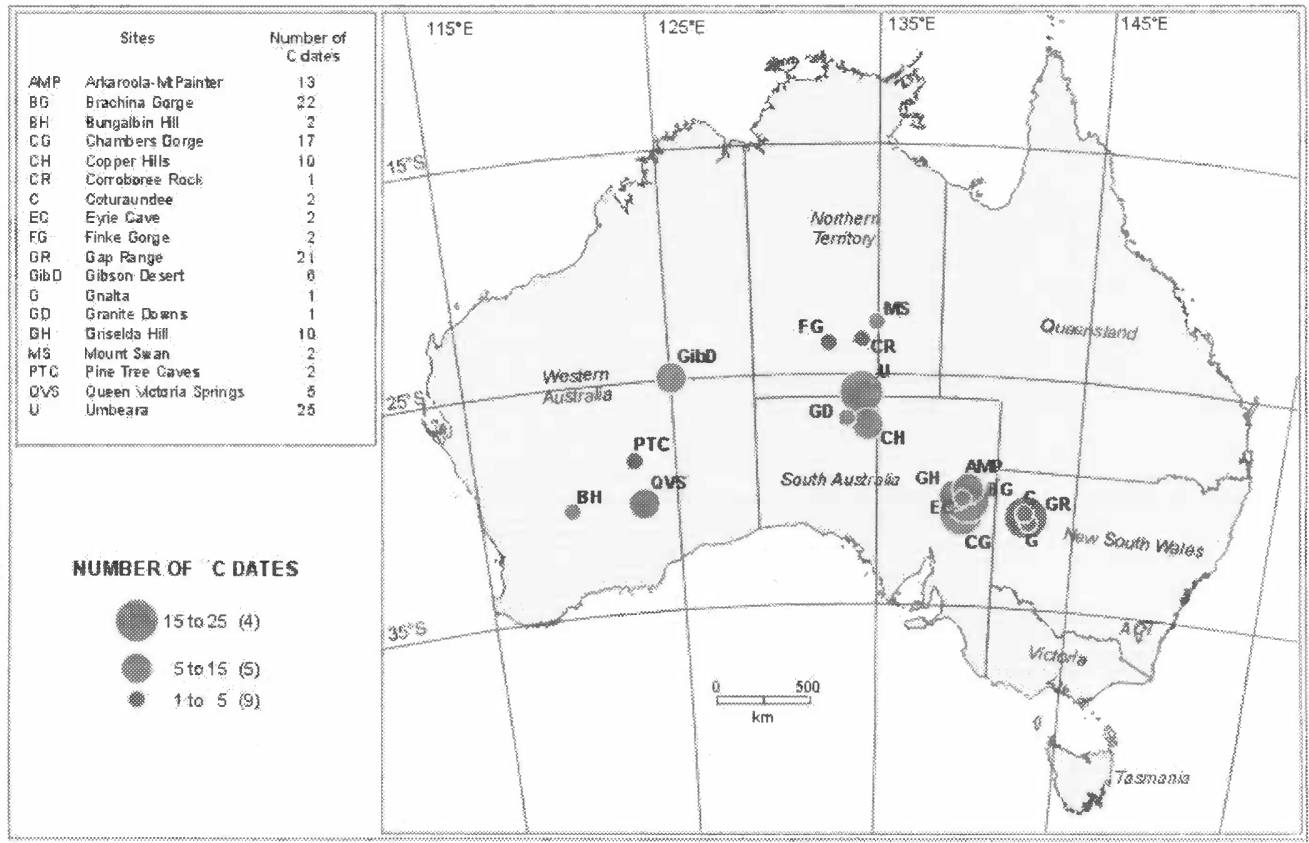

Figure 3 Map showing the distribution of stick-nest rat midden study sites and radiocarbon dates 


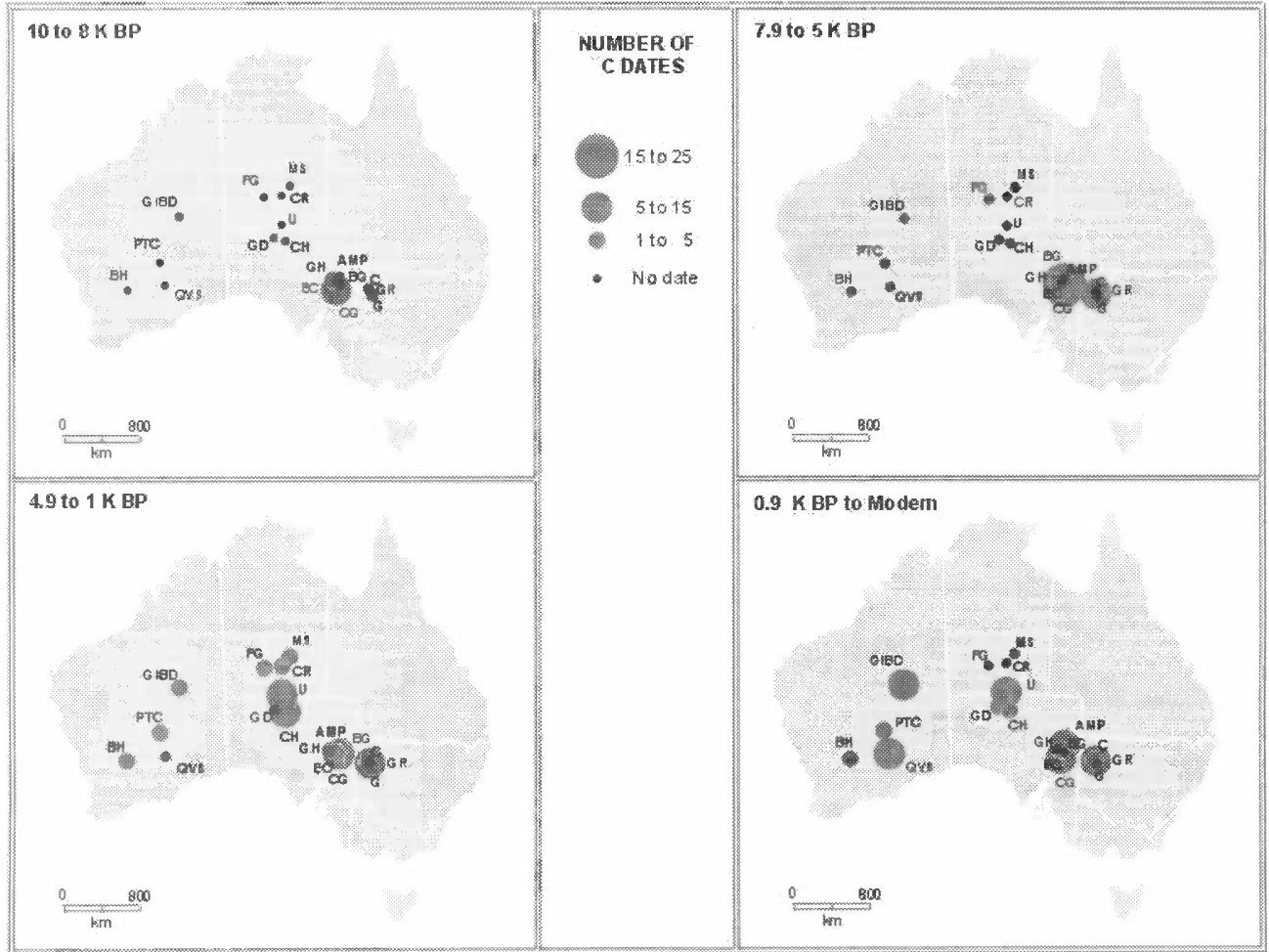

Figure 4 Maps showing the changing distribution of radiocarbon dates on middens

ka cal BP

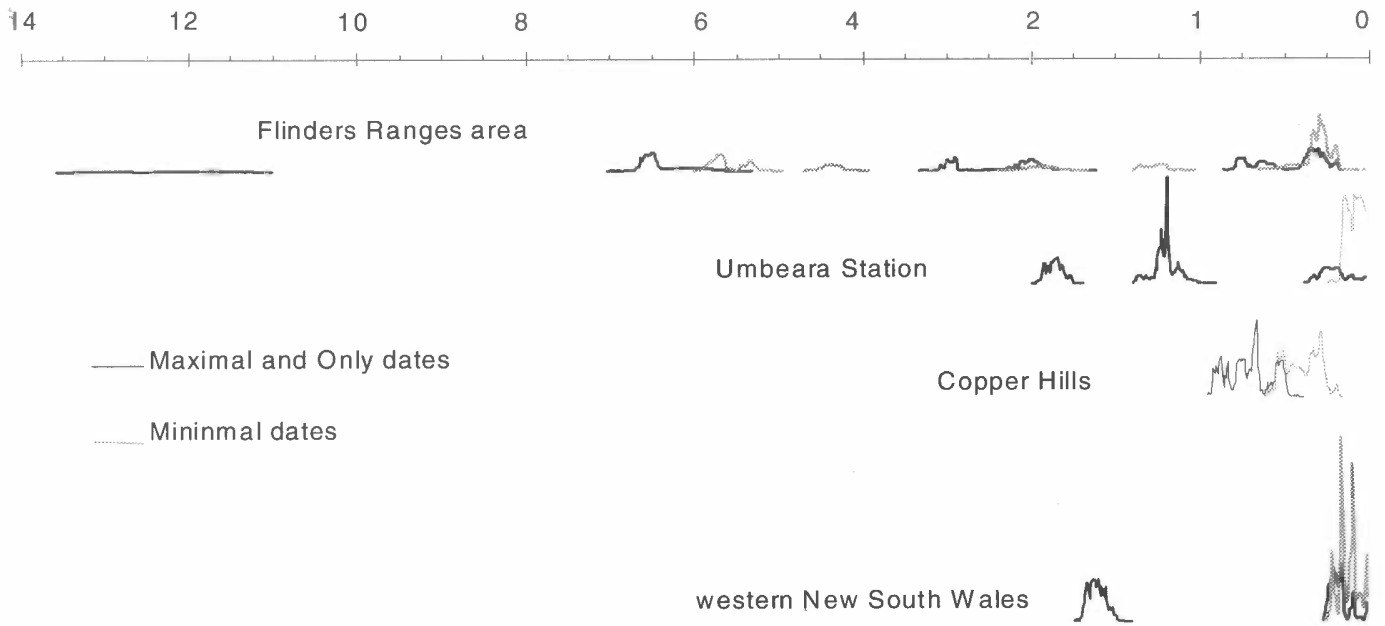

Figure 5 Maximal and minimal calibrated radiocarbon dates on middens from 4 sites: Copper Hills, Umbeara Station, Flinders Ranges area and western New South Wales 


\section{DISCUSSION}

Analysis of the spatial and temporal distribution of stick-nest rat midden ages suggests that some important issues still need to be addressed by researchers. The advances in midden analysis are clearly evident in the changes in the material being dated, the detailed information now available about the preservation bias underlying the distribution of middens, the awareness of the ecological significance of the midden record, the detailed understanding of the age of individual middens, and regional difference between groups of middens at the few sites studied in detail. The direction of future research is suggested by these results and through comparisons with North America (Pearson and Betancourt 1999).

The extensive sampling of stick-nest rat middens is remarkable. However, only a fraction of the known distribution has been sampled (Pearson 1999). Accessibility by road has played an important role in midden collection and possibly in accelerating midden decay. Middens were destroyed by subfossil collectors and dingo hunters using access roads and tracks. As a result, the accessible middens are possibly the most damaged and also the most sampled. If so, there are likely to be older and less disturbed midden deposits in more isolated areas, but they would be very costly to sample.

${ }^{14} \mathrm{C}$ analyses of stick-nest rat middens (Table 2) have changed from bulk conventional dates of unsorted midden material (Green et al. 1983), to AMS dates using small samples (Pearson 1997; McCarthy et al. 1996). Stick-nest rat skin and pollen residues have also been dated. The American trend has been towards dating scats (21\% by 1985; Webb and Betancourt 1990) and in Australia, dates are frequently (38\%) on scats. Dating of a single taxon (e.g. most often Juniperus sp., an indicator of cooler climates when recovered from a fossil midden in low desert thorn scrub) is unique to America [Van Devender 1973; Mead et al. 1978]) and accounted for over $41 \%$ of all the midden dates in 1985 (Webb and Betancourt 1990). Special grants from the Australian Institute for Nuclear Science and Education (AINSE) yielded a much higher proportion of AMS dates from stick-nest rat middens (66\%) than from packrat middens (4\%), and Australian researchers have had more control on questions of contamination and resolution.

TABLE 2 Types of material dated from middens

\begin{tabular}{l|cc}
\hline Material & $\begin{array}{c}\text { Australia } \\
(\mathrm{n}=145)\end{array}$ & $\begin{array}{c}\text { American } \\
(\mathrm{n}=1113)^{\mathrm{a}}\end{array}$ \\
\hline Scat & $35 \%$ & $0 \%$ \\
Scats & $3 \%$ & $21 \%$ \\
Plant fragments & $>25 \%$ & $38 \%$ \\
Single taxa & $4 \%$ & $41 \%$ \\
\hline
\end{tabular}

${ }^{a}$ Webb and Betancourt (1990)

Midden analysts use ${ }^{14} \mathrm{C}$ to constrain the age of interesting material by direct dating (e.g. the skin of the stick-nest rat), indirectly dating the material by assuming adjacent material is contemporaneous (e.g. analyzing selected macrofossils next to a pollen sample), and bracketing samples above (i.e. minimal date) and below (i.e. maximal date) the material of interest. All 3 methods have been used in stick-nest rat midden research, although packrat researchers have largely used direct dating. Most exploratory dates in Australia have used material at the base of the deposit to find the maximum length of the record (Table 1; Figure 2), so older samples are possibly over-represented. This is the most efficient way to find the oldest materials. Fewer dates have been used to constrain the minimal age of the deposits (Table 1). Many middens have been dated once to ascertain if further research and dating would be worthwhile. 
Accumulation rates can be calculated using ${ }^{14} \mathrm{C}$ dates that constrain accumulations of measured depth. ${ }^{14} \mathrm{C}$ dates from a number of middens and sites in central Australia suggest accumulation rates are about $0.31 \pm 0.7 \mathrm{~mm}$ per year, so a midden of $300 \mathrm{~mm}$ depth may reflect over $1000 \mathrm{yr}$ of accumulation (Pearson 1997). Flinders Ranges middens have a depositional rate that may be more rapid over discrete periods of time. For example, at Brachina Gorge, a midden accumulated a few hundred years of material in a depth of $600 \mathrm{~mm}$. Analysts in Australia appear to have routinely explored the stratigraphy of middens in more detail than their American counterparts (e.g. Pearson 1989; Head et al. 1998). However, it is clear that middens do not accumulate continually or vertically because ${ }^{14} \mathrm{C}$ results are anomalous and dusty weathering layers occur throughout the midden. The American packrat researchers have not used interpolated ages for samples in their analyses; instead each sample is selected to avoid layers separated by weathering rinds. The samples are then ${ }^{14} \mathrm{C}$-dated and assumed to be contemporaneous. This difference reflects the ready access to ${ }^{14} \mathrm{C}$ analyses in the United States and perhaps the dominantly palynological background of the current researchers in Australia.

Systematic bias in sampling packrat middens for ${ }^{14} \mathrm{C}$ resulted in a marked bimodal distribution of American midden dates (Webb and Betancourt 1990). This is probably the result of an exponential decline in midden preservation through time, the abundance and easy identification of extra-local species around $8500 \mathrm{BP}$ to $10,000 \mathrm{BP}$ and older, and a lack of ecological change in the late Holocene. However, even late prehistoric dominance of arid land shrubs may change and be detected in late-Holocene middens. Packrat middens older than 8000 BP routinely contain macrofossils of plants that no longer occur at the site, or groups of species that are no longer sympatric. These data are used to preselect middens that will address the questions about vegetation composition change. Since these changes are ecologically the most interesting, the older middens have received more attention reflecting the efficiency of paleoecological sampling when indicator macrofossils are obvious. This results in a bimodal distribution of packrat midden dates with 2 underlying decay curves (Webb and Betancourt 1990). Hall (1997) has said that this selective process, along with the cliff-edge position of ancient middens, causes distortion in the vegetation reconstructed from middens. American researchers have also sought to identify contaminates through dating and redating some samples; this tends to further distort the distribution of ${ }^{14} \mathrm{C}$ dates.

In contrast, the samples in Australian stick-nest rat middens have not been preselected by indicator taxa. Instead, middens are dated "blind" because the midden contents appear very uniform regardless of their antiquity. The appearance and shape of middens had been assumed to be poor predictors of midden age. However, Head et al. (1998) suggest a categorization of midden structure to preselect middens for reliable paleoecological analysis in western New South Wales. The decay of middens through time is reflected by a monotonic curve of ${ }^{14} \mathrm{C}$ analyses (Figure 1). The pattern is the same when maximal and minimal midden ages are considered (Figure 2). Pearson's (1997) Umbeara sites and Head et al.'s (1998) Gap Range sites in western New South Wales do not suffer this selection bias but the distributions still follow a similar pattern of all the midden dates (Figure 5).

The existence of middens is predicated on the presence of a population of midden-building animals and the availability of suitable and sufficient biomass for midden construction. From the observations of midden construction elsewhere, middens will generally be built (and therefore more likely found) at times of increased productivity (Betancourt and Van Devender 1981). Factors controlling stick-nest rat midden activity include the existence of a viable metapopulation to occupy suitable sites, mortality below recruitment, and the satisfaction of nutritional and habitat requirements. Interpretation of the existence of middens in the landscape must take into consideration all these aspects. It is possible that stick-nest rat activity correlates with climatic variables of interest. 
In the United States, there is a period between 4000 and $8000 \mathrm{BP}$ during which there is a decline in the number of ${ }^{14} \mathrm{C}$ analyses available on middens. Webb and Betancourt (1990) suggested that a single cause was unlikely because the phenomenon is widespread across the Chiuahuan, Sonoran and Mojave Deserts, as well as the Great Basin and the Colorado Plateau. There is also a dearth of packrat middens from higher altitude sites $(2500 \mathrm{~m})$ at peak aridity $(10,000 \mathrm{BP})$. Low productivity of the ecosystems probably makes the survival of packrats or accumulation of organic material unlikely. At one site, Betancourt and Van Devender (1981:656) suggested that, "packrat middens measure resource availability" and that a lack of middens in a particular age range may indicate a period of low productivity. The brief occurrence of rodent middens in the Atacama Desert of Chile reflects a small window of Holocene productivity (J Betancourt, personal communication 1999). Although gaps in the midden record in Australia may relate to periods of very low productivity, it is unlikely that this aspect of the record can be understood from current Australian research due to the extinction of stick-nest rats. The record may be partly solved through the continuing work at other sites.

We believe that there are sufficient ${ }^{14} \mathrm{C}$ samples, selected from a variety of sites including volcanic, metamorphic and sedimentary substrates, to show the pattern of midden decay in Australia (Figure 1). The spatial distribution of middens is discontinuous and there are sites with caves suitable for midden preservation that do not contain middens. The absence of middens could relate to extremely long periods of midden decay or a real absence of stick-nest rats at the sites. Factors that may speed the process of midden decay include periods of high humidity, bioturbation, and severe fires. Further work needs to be done to compare the distribution of subfossil stick-nest rat bone and the midden material to identify where the midden builders have been but the middens have not survived. The dearth of Glacial or early Holocene midden dates (Figure 2) may reflect a real lack of middens built during this period. Records from the continental margins suggest the arid cores suffered very low plant productivity and high ecological stress during the Last Glacial Maximum (Kershaw 1995). If productivity was extremely low, the small rodent population would build few middens and those that were built would be unlikely to survive long enough to contribute to our understanding of the arid zone's paleoecology. There are patterns in the maximal and minimal dates of middens suggesting that periods of accumulation and abandonment may be cyclic (Figures 2 and 5 ), although there is no synchronicity in either maximal or minimal dates between sites.

Most of the paleoenvironmental records and models suggest that Australian ecosystems have probably been stable for the last $4000 \mathrm{yr}$ (Markgraf et al. 1992). So, the late Holocene age of most middens analyzed in Australia reduces the likelihood of major ecological change being encountered in the record. The one midden of late Glacial Maximum age does not appear to record a major environmental change in either the pollen or the macrofossil record (McCarthy et al. 1996). A comparison of northern and central Flinders Ranges middens by McCarthy et al. (1996) indicated more spatial variability in vegetation composition and structure between sites after $2000 \mathrm{BP}$, suggesting that local topography may buffer vegetation change. Apart from these middens, and other evidence from the arid zone (Smith et al. 1995), this suggests that at some sites the distribution of many arid plants and the composition of communities predate the mid-Holocene.

\section{CONCLUSION}

In Australia, extra-local taxa that would help in building a chronology have not been identified, and the age distribution of middens is less distorted by an "early-Holocene push" that characterizes the ${ }^{14} \mathrm{C}$ results on American packrat middens. We have not been able to identify with certainty any major shift in taxa, perhaps because the midden record is currently limited to the late HoloceneModern period. This may be because the changes in the late Holocene are within the natural vari- 
ability of the modern ecosystem or in the small to medium-scale spatial response of the vegetation signal.

Generally, appearance and architecture have not been found to be reliable indicators of stick-nest rat midden age, so middens have been dated without effective preselection. This has resulted in a unimodal distribution of ${ }^{14} \mathrm{C}$ ages in Australia rather than a bimodal distribution as in America. In the future, that pattern may change with the typologies developed by Head et al. (1998) to identify the stick-nest rat middens more likely to hold paleoclimatic records.

The availability of a paleoecological record determines which research questions can be addressed. Midden analysts may now expand from the search for biogeographic changes to study the inertia and plastic responses of taxa in the Australian arid zone. Further work using chemical and structural characteristics of macrofossils, or more emphasis on macrofossil identifications with adequate reference material, may be fruitful - particularly given the availability of well-dated midden materials. There is certainly still scope for the discovery of middens in areas likely to be sensitive to particular kinds of regional changes. The most dramatic finds would be at sites where changes in species composition were forced by a variable of interest (e.g. rainfall), and the changes were then recorded in midden materials. The search continues for these sites, or records from sites already sampled. The authors hope this paper contributes to the greater efficacy of stick-nest rat midden analysis in Australia.

\section{ACKNOWLEDGMENTS}

The Flinders Ranges and western New South Wales work was funded by an Australian Research Council (ARC) grant to LH. Fieldwork in the Northern Territory was funded by an ARC grant to JD. An ARC grant for Quaternary projects established by JD in 1993 funded many of the AMS dates through AINSE with grants to JD, LH and SP. This is publication 36 of the Geomorphology and Quaternary Science Research Unit, Department of Geography and Environmental Science, University of Newcastle. The draft benefited from discussions with Julio Betancourt and comments of Paul Martin. Graeme Medlin and Colin Dollery discussed the distribution of middens in Queensland. Maps were drawn by Olivier Rey-Lescure.

\section{REFERENCES}

Berry SL. 1993. The potential of fossil middens as indicators of vegetation history in central Australia. Australian Journal of Botany 39:305-13.

Betancourt JL, Van Devender TR. 1981. Holocene vegetation in Chaco Canyon, New Mexico. Science 214: 656-8.

Betancourt JL, Van Devender TR, Martin PS, editors. 1990. Packrat middens: the last 40,000 years of biotic change. Tucson: University of Arizona Press. 467 p.

Bowdery D. 1998. Phytolith analysis applied to Pleistocene-Holocene archaeological sites in the Australian arid zone. Oxford: British Archaeological Reports International Series 695: $216 \mathrm{p}$.

Copley P. 1988. The stick-nest rats of Australia. Adelaide: Department of Environment and Planning: 277 p.

Elias SA, Van Devender TR, De Baca R. 1995. Insect fossil evidence of late glacial and Holocene environments in the Bolson de Mapimi, Chihuahuan Desert, Mexico: comparisons with the paleobotanical record.
Palaios 10:454-64.

Green N, Caldwell J, Hope J, Luly J. 1983. Pollen from an 1800 year old stick-nest rat midden from Gnalta, Western New South Wales. Quaternary Australia 1: $31-41$.

Hall S. 1997. Pollen analysis and woodrat middens: Reevaluation of Quaternary vegetational history in the American southwest. Southwestern Geographer 1: 25-43.

Head L, McCarthy L, Quade J, Witter D, Allen V, Lawson E. 1998. Classification and radiocarbon dating of Leporillus nests in semi-arid Australia and palaeoclimatic implications. Palaeoclimates 3:161-77.

Kershaw AP. 1995. Environmental change in greater Australia. Antiquity 69:665-75.

Long A, Warneke LA, Betacourt JL, Thompson RS. 1990. Deuterium variations in plant cellulose from fossil packrat middens. In: Betancourt JL, Van Devender, TR, Martin PS, editors. Packrat middens: the last 40,000 years of biotic change. Tucson: University 
of Arizona Press: 380-96.

Lowenstein JM, Rainey WN, Betancourt JL. 1991. Immunospecific albumin in fossil pack rat, pocupine and Hyrax urine. Naturwissenschaften 78: 26-7.

McCarthy L, Head L, Quade J. 1996. Holocene palaeoecology of the northern Flinders Ranges, south Australia, based on stick-nest rat (Leporillus spp.) middens: A preliminary overview. Palaeogeography Palaeoclimatology, Palaeoecology 123:205-18.

Markgraf V, Dodson JR, Kershaw AP, McGlone MS, Nicholls N. 1992. Evolution of late Pleistocene and Holocene climates in the circum-South Pacific land areas. Climate Dynamics 6:193-211.

Mead JI, Phillips AM. 1981. The late Pleistocene and Holocene fauna and flora of Vulture Cave, Grand Canyon, Arizona. The Southwestern Naturalist 26(3): 257-88.

Mead JI, Thompson RS, Long A. 1978. Arizona Radiocarbon Dates IX: carbon isotopes dating of packrat middens. Radiocarbon 20(2):171-91.

Mead JI, Van Devender TR, Cole KL. 1994. Late Quaternary small mammal remains from Sonoran packrat middens, Arizona and California. Journal of Mammalogy 64: 173-80.

Pearson S. 1989. Stick-nest rat middens as pollen samples for palaeo-environmental studies [BA honors thesis]. Sydney (New South Wales): School of Geography, Faculty of Science, University of New South Wales. $91 \mathrm{p}$.

Pearson S. 1997. Stick-nest rat middens as a source of palaeo-environmental data in central Australia [dissertation]. Sydney (New South Wales): School of Geography, Faculty of Science, University of New South Wales. 314 p.

Pearson S. 1999. Late Holocene biological records from the middens of stick-nest rats in the central Australian arid zone. Quaternary International 59:39-46.

Pearson S, Baynes A, Triggs B. 1999. The fauna identified from hair and bone in middens of stick-nest rats (Muridae: Leporillus spp.) and the accumulating agents. Australian Journal of Ecology: Submitted.

Pearson S, Betancourt JL. 1999. Comparison of American packrat and Australian stick-nest rat midden research: A guide to future work in Australia and other continents. Journal of Quaternary Science: Submitted.

Pearson S, Dodson JR. 1993. Stick-nest rat middens as sources of paleoecological data in Australian deserts. Quaternary Research 39:347-54.

Pedler L, Copley PB. 1993. Re-introduction of stick-nest rats to Reevesby Island South Australia. Adelaide: World Wildlife Fund Australia. Project Nr 175. 29 p.

Pendall E, Betancourt JL, Leavitt SW. 1999. Palaeoclimatic significance of delta $\mathrm{D}$ and delta $13 \mathrm{C}$ values in piñon pine needles from packrat middens spanning the last 40,000 years. Palaeogeography, Palaeoclimatology, Palaeoecology 147:53-72.
Plummer MA, Phillips FM, Fabryka-Martin J, Turin HJ, Wigand PE, Sharma P. 1997. Chlorine-36 in fossil rat urine: an archive of cosmogenic nuclide deposition during the past 40,000 years. Science 277:538-41.

Rogers SO, Bendich AJ. 1985. Extraction of DNA milligram amounts of fresh, herbarium and mummified plant tissues. Plant Molecular Biology 5:69-76.

Smith MA, Vellen L, Pask J. 1995. Vegetation history from archaeological charcoals in central Australia: The late Quaternary record from Puritjarra rock shelter. Vegetation History and Archaeobotany 4:171-7.

Strahan R, editor. 1995. The mammals of Australia. Sydney: Reed. 756 p.

Stuiver M, Reimer PJ. 1993. Extended ${ }^{14} \mathrm{C}$ database and revised CALIB radiocarbon calibration program, $R a$ diocarbon 35(1): 215-30.

Stuiver M, Reimer PJ. 1998. Calib 4.0 Manual [www document] Seattle: Quaternary Research Centre, University of Washington, URL: <http://depts.washington.edu/qil/calib/manual/index.html> Accessed 1999 Feb 22.

Stuiver M, Reimer PJ, Bard E, Beck JW, Burr GS, Hughen KA, Kromer B, McCormac FG, van derPlicht J, Spurk M. 1998. INTCAL98 radiocarbon age calibration, 24,000-0 cal BP. Radiocarbon 40(3):104183.

Stuiver M, Reimer PJ, Braziunas TF. 1998. High-precision radiocarbon age calibration for terrestrial and marine samples. Radiocarbon 40(3): 1127-51.

Van de Water PK, Leavitt SW, Betancourt JL. 1994. Trends in stomatal density and ${ }^{13} \mathrm{C} /{ }^{12} \mathrm{C}$ ratios of Pinus flexilis needles during last glacial-interglacial cycle. Science 264:239-43.

Van Devender TR. 1973. Late Pleistocene plants and animals of the Sonoran desert: a survey of ancient packrat middens in SW Arizona [dissertation]. Tucson: University of Arizona. $179 \mathrm{p}$.

Van Devender TR, Martin PS, Thompson RS, Cole KL, Jull, AJT, Long A, Toolin LJ, Donahue DJ. 1985. Fossil packrat middens and the tandem accelerator mass spectrometer. Nature 317:610-13.

Van Devender TR, Toolin LJ, Burgess TL. 1990. The ecology and paleoecology of grasses in selected Sonoran desert plant communities. In: Betancourt JL, Van Devender TR, Martin PS, editors. Packrat middens: the last 40,000 years of biotic change. Tucson: The University of Arizona Press. p 326-49.

Webb RH. 1986. Spatial and temporal distribution of radio-carbon ages on rodent middens from the southwestern United States. Radiocarbon 28(1):1-8.

Webb RH, Betancourt JL. 1990. The spatial and temporal distribution of radiocarbon ages from packrat middens. In: Betancourt JL, Van Devender TR, Martin PS, editors. Packrat middens: the last 40,000 years of biotic change. Tucson: The University of Arizona Press. p 85-102. 